\title{
ANALYSIS OF MODIFICATIONS ON A SPARK IGNITION ENGINE FOR OPERATION WITH NATURAL GAS
}

\author{
D. Ramasamy ${ }^{1,2}$, M.M. Noor ${ }^{1,3}$, K. Kadirgama ${ }^{1}$, M.M. Rahman ${ }^{1}$, W.G.B. Horizon ${ }^{2}$ \\ ${ }^{1}$ Faculty of Mechanical Engineering, Universiti Malaysia Pahang, 26600 Pahang, Malaysia \\ ${ }^{2}$ Focus Applied Technologies, 6305 Highland PI, Black Forest CO 80908 USA. \\ ${ }^{3}$ Department of Mechanical Engineering, University of Southern Queensland, Australia \\ E-mail: deva@ump.edu.my/muhamad@ump.edu.my, contact: +6094246359
}

\begin{abstract}
Transportation is one of the key contributors to petroleum usage and emissions to the atmosphere. According to researchers, there are many ways to use transport by using renewable energy sources. Of these solutions, the immediate solution which requires less modification to current engine technology is by using gaseous fuels. Natural gas is the fuel of choice for minor modification to current engines. As it can be derived from anaerobic digestion process, the potential as a renewable energy source is tremendous, especially for an agricultural country such a Malaysia. The aim in the future will be operating an engine with natural gas only with pipelines straight to houses for easy filling. The fuel is light and can be easily carried in vehicles when in compressed form. As such, Compressed Natural Gas (CNG) is currently used in bi-fuel engines, but is mostly not optimized in term of their performance. The focus of the paper is to optimize a model of natural gas engine by one dimensional flow modeling for operation with natural gas. The model is analyzed for performance and emission characteristics produced by a gasoline engine and later compared with natural gas. The average performance drop is about $15 \%$ from its gasoline counterpart. The $4 \%$ benchmark indicates that the modification to ignition timing and compression ratio does improve engine performance using natural gas as fuel.
\end{abstract}

\section{Introduction}

Future energy needs is demanding and the use of petroleum as one of the main source of energy is leading to fuel depletion in many countries in the world [1-3]. Malaysia being an oil producing country has slowly reducing reserves as shown in Figure 1 [4, 5]. Consequently, petroleum price in Malaysia increased in price due to high demand in the world market. As vast amount of petroleum is used in the transportation sector, many alternatives have been introduced for the past few decades to reduce petroleum consumptions as well as reducing emissions. Of these alternatives only natural gas in compressed form and liquefied petroleum gas (LPG) appear to be more economic for worthy implementation $[6,7]$. Since LPG is totally derived totally from petroleum, natural gas is a better choice of fuel as it can be obtained from non-petroleum sources [8]. Natural gas is derived from biogenic (transformation of organic matter) and abiogenic (from earth crust) processes. The gas is abundant and world production prediction is reaching to 155.5 trillion cubic feet (tcf) from 106.6 tcf from year 2007 to year 2035[4].

The important of natural gas to the engine combustion was applied to several applications [9]. In Malaysia the natural gas production, consumption and exports shows gradual production increase as compared to petroleum production. Figure 2 shows the current trend in natural gas usage in Malaysia [4]. Malaysia has the 8th largest reserves of natural gas with 83 tcf and producing 2.3 tcf as of year 2007. This ranking dropped in one year to 14 th even though the reserve stood at 88 tcf [10]. More diversified methods are required for the gas production to be increased. The low demand of gas consumption compared to future production indicates the country is lacking gas fuelled technologies. However, more usage in vehicles is required to reduce the petroleum consumption.

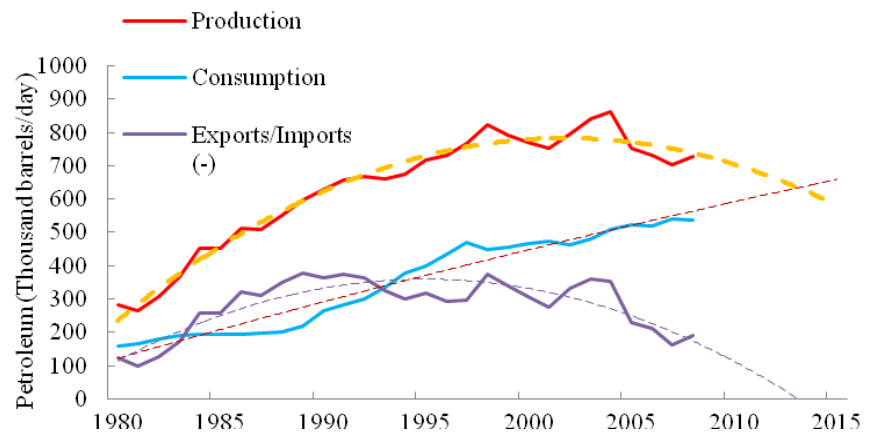

Figure 1: Petroleum Production in Malaysia (Ghosh and Prelas 2009) 


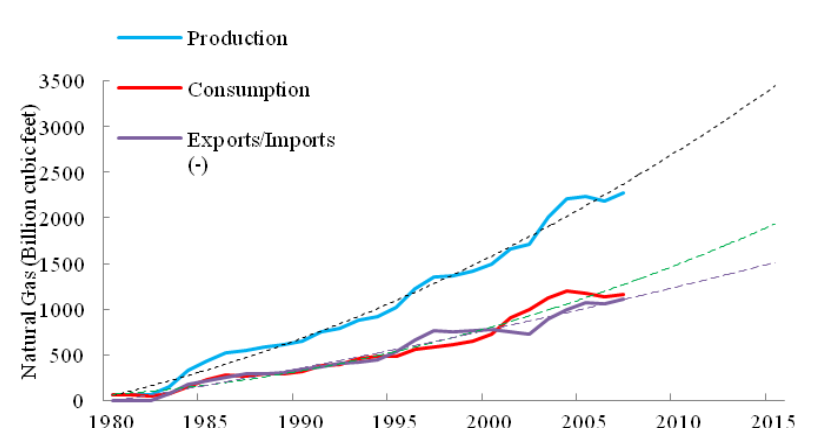

Figure 2: Malaysian Natural Gas Usage

To promote natural gas vehicles is a future target to reduce cost of operation of buses and cars. The country is an agricultural based country, planting crops such as oil palm, rubber, rice, mixed horticulture and coconut [11]. The waste products gathered from the plants is capable of producing natural gas from biogenic process. Biochemical methane potential (BMP), from crops and food using anaerobic digestion (AD) can reach up to 161$240 \mathrm{~m} 3 \mathrm{CH} 4$ /ton [12]. As Malaysia is producing 15000 tons of solid waste per day the amount of Methane generation will be around $3000000 \mathrm{~m} 3$. This source of methane is feasible to be used in vehicular usage.

Research for gas powered vehicles is required to reduce dependency to petroleum. This can be very beneficial to future energy cost in the country. This paper outlines engine testing with natural gas for a common car engine in Malaysia. A one dimensional approach shows how much power and emission is generated by natural gas usage. The result is compared with a gasoline counterpart simulation to get a benchmark of power loss due to fuel exchange. A minor optimization to the engine's compression ratio and ignition timing is done with natural gas so that the energy of the fuel is harnessed fully.

\section{Engine Specification}

The engine targeted for testing is a Perodua Myvi car engine named K3-VE, it has specification as in Table 1 below.

Table 1: Myvi Engine Specification

\begin{tabular}{ll}
\hline Engine Type & 4-Stroke, EFI \\
\hline Cylinders & 4 inline \\
Bore x Stroke $(\mathrm{mm})$ & $72.0 \times 79.7$ \\
Displacement $(\mathrm{cc})$ & 1298 \\
Compression Ratio & $10: 1$ \\
Max. Output $(\mathrm{kW} / \mathrm{rpm})$ & $63 / 600$ \\
Maximum torque $(\mathrm{Nm} / \mathrm{rpm})$ & $120 / 3200$
\end{tabular}

Valve timing

Intake valve open

BTDC, $30^{\circ}$ to $(-12)^{\circ}$

Intake valve close

Exhaust valve open

$\mathrm{ABDC}, 10^{\circ}$ to $52^{\circ}$

$\mathrm{BBDC}, 30^{\circ}$

Exhaust valve close

ATDC, $2^{\circ}$
Table 2 shows the specification of the fuel that was used in the simulation. As natural gas has higher octane rating it has the capability to be compressed and ignite earlier. In doing this the higher energy content of the fuel is targeted to be fully optimized. 1-Dimensional engine simulation software, was used. The simulation software provides the guidelines to modify the engine. The simulation results will provide a strong example of how the engine behaves after modification. With the simulation results, decisions of which compression ratio and ignition timing map to be use can be made easily. The general setup of the software is shown in Figure 3 below.

Table 2 Fuel Spécifications (Heywood 1988, S. Maji 2000, Ramasamy, Aik Soon et al. 2013)

\begin{tabular}{|c|c|c|}
\hline Fuel & Gasoline & $\mathrm{CNG}$ \\
\hline Phase $\left(25^{\circ} \mathrm{C}\right)$ & Liquid & Gas \\
\hline Stoichiometric A/F Ratio & 14.7 & 14.5 \\
\hline Energy Content, $\mathrm{MJ} / \mathrm{Kg}$ & 44 & 50 \\
\hline Composition & $\begin{array}{l}\text { Complex } \\
\text { Hydrocarbon }\end{array}$ & $\begin{array}{l}92.73 \% \\
\text { Methane }\end{array}$ \\
\hline Octane Rating & $80-90$ & 120 \\
\hline $\begin{array}{l}\text { Flame Speed in air at } \\
\text { stoichiometric, } \mathrm{mm} / \mathrm{s}\end{array}$ & 390 & 375 \\
\hline Autoignition Temperature & $480 \sim 550{ }^{\circ} \mathrm{C}$ & $537^{\circ} \mathrm{C}$ \\
\hline
\end{tabular}

\section{Methodology}

As discussed earlier in, the capabilities of the natural gas to be ignited earlier and compressed is tested out in the 1 dimensional simulation. Two criteria were identified for the simulation which are the ignition timing advancing for more fuel energy harvesting and compression ratio modification for increasing the fuel compression. The ignition timing of the engine has to be advanced to compensate the slow burn rate of the compressed natural gas. The ignition timing will be varied from $60^{\circ}$ before top dead center (BTDC) to $30^{\circ}$ after top dead center (ATDC). Engine power, torque, and combustion data will be taken with varying the ignition timing at fixed engine speed. With the simulation data, the ignition timing can be optimized for maximum brake power and torque.

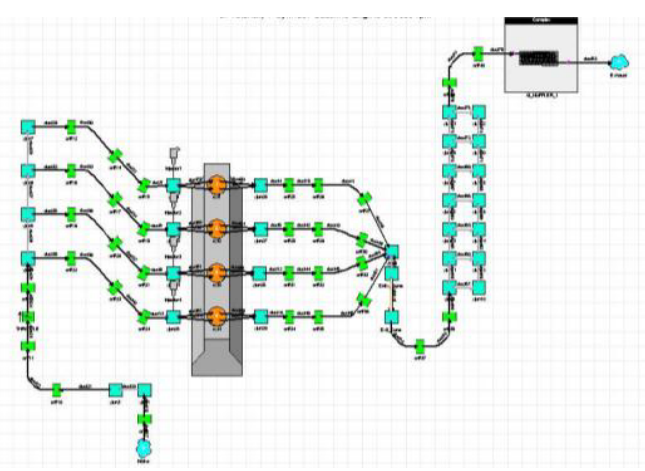

Figure 3: 1-Dimensional Simulation 
The compression ratio was focus in this research. As compression ratio increase, the thermal efficiency of the engine will increase and this will increase the overall efficiency of the engine. This is shown in Figure 4. The octane number of compressed natural gas is 120 . This allows the engine to run on higher compression ratio (Debnath, Sahoo et al. 2013). However higher compression ratio will induce knock to the engine. This can be simulated in the simulation software. The power curve and torque curve will be collected at different compression ratio (Korakianitis, Namasivayam et al. 2011). The compression ratio will be varied from 10 to 18. The knock plot will also be collected.

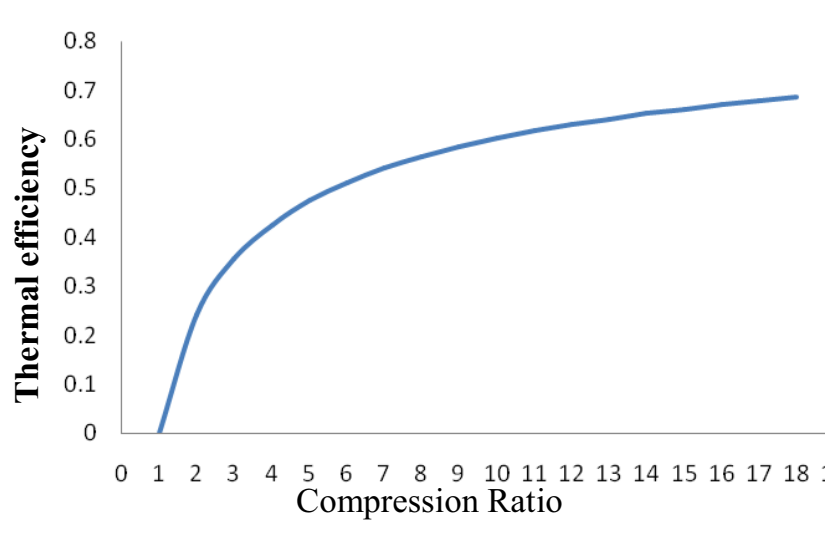

Figure 4: Thermal efficiency against different compression ratio

\section{Results And Discussion}

The result of the knock intensity at different compression ratio and ignition timing were presented. As compression ratio increases the knock intensity at low speed increases dramatically. This is due to the air fuel mixture has enough time to be influenced by the temperature of the combusted mixture. Similar result was found by [8, 18].Therefore at low speed the engine ignition timing needs to be advanced. Figure 5 to 8 shows the knock intensity at different engine speed and at different mass burn ratio of $50 \%$ crank angle.

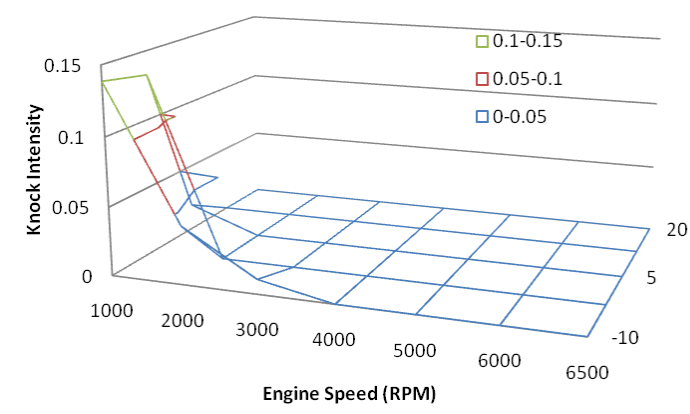

Figure 5: Knock intensity at compression ratio 12 at various different mass burn ratio of $50 \%$ crank angle

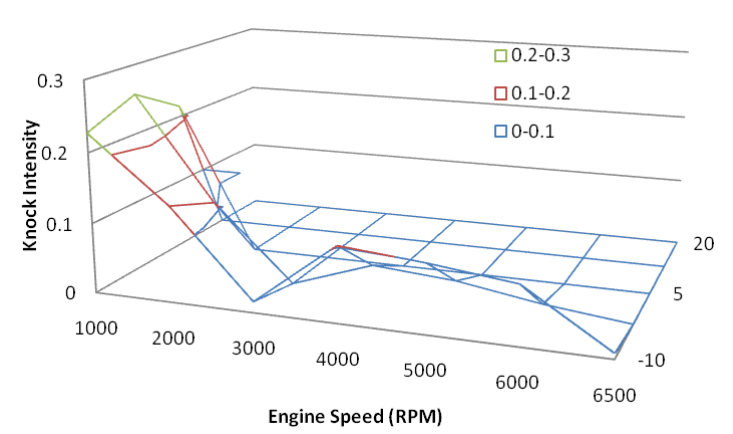

Figure 6: Knock intensity at compression ratio 14 at various different mass burn ratio of $50 \%$ crank angle

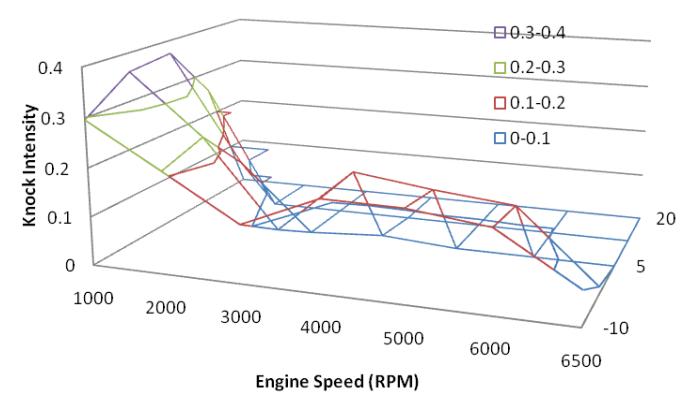

Figure 7: Knock intensity at compression ratio 16 at various different mass burn ratio of $50 \%$ crank angle

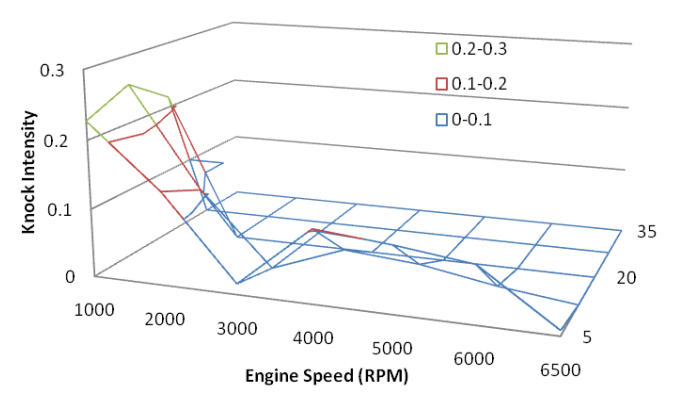

Figure 8: Knock intensity at compression ratio 18 at various different mass burn ratio of $50 \%$ crank angle

The power and torque curve at different compression ratio and ignition timing was discussed. Figure 9 to Figure 12 below shows the power and torque curve at different mass burn ratio of $50 \%$ crank angle. The effect of compression ratio to the power and torque curve diminishes as compression ratio increases (Caris and Nelson 1959, White, Steeper et al. 2006, Ramasamy, Zainal et al. 2014). Also, at low engine speed that is below $3000 \mathrm{rpm}$ the ignition timing has to be advanced. However, above $3000 \mathrm{rpm}$ the ignition timing needs to be retarded. The ignition timing is analyzed for 5 points from the baseline $\mathrm{CNG}$. They are $10^{\circ} \mathrm{CA}$ BTDC, $2.5^{\circ} \mathrm{CA}$ $\mathrm{BTDC}, 5^{\circ} \mathrm{CA}$ ATDC, $12.5^{\circ} \mathrm{CA}$ ATDC and $20^{\circ} \mathrm{CA}$ ATDC. The negative denotes the piston position before TDC. Compression ratio 18 was ruled out due to the varying angle is too much, and it can compromise engine stability. 


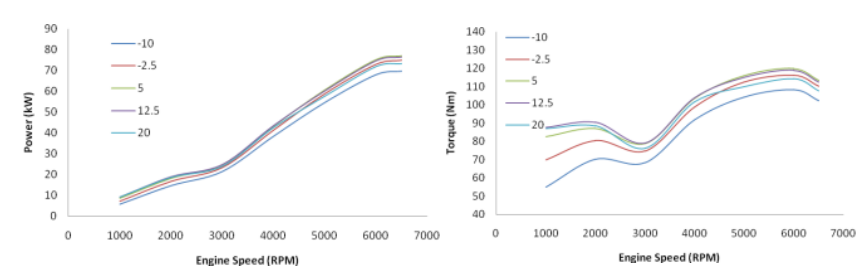

Figure 9: Power and torque curve at compression ratio 12 at various different mass burn ratio of $50 \%$ crank angle
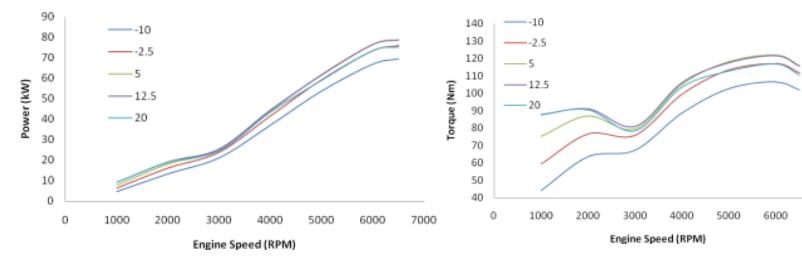

Figure 10: Power and torque curve at compression ratio 14 at various different mass burn ratio of $50 \%$ crank angle
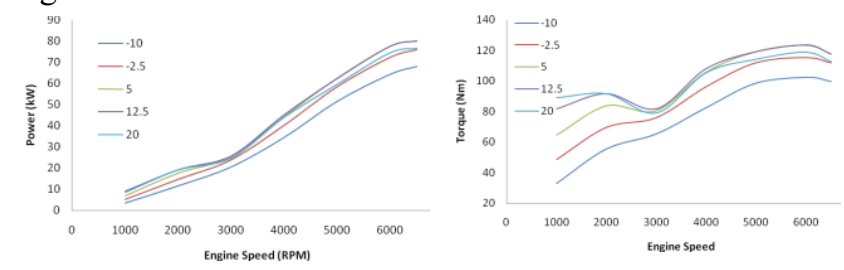

Figure 11: Power and torque curve at compression ratio 16 at various different mass burn ratio of $50 \%$ crank angle
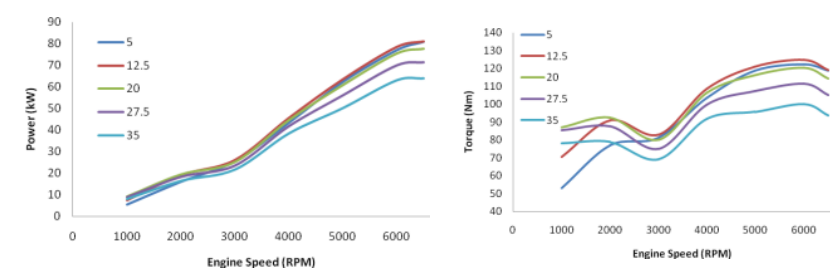

Figure 12: Power and torque curve at compression ratio 18 at various different mass burn ratio of $50 \%$ crank angle

Figure 13 shows the power and torque curve of gasoline and $\mathrm{CNG}$ without any modification. The average performance drop is about $19 \%$ from its gasoline counterpart (Anderson 2012, Vijayakumar, Ponnalagi et al. 2013, Ramasamy, Zainal et al. 2014). Figure 14 shows the power and torque curve of gasoline and $\mathrm{CNG}$ with compression ratio and ignition timing optimization achieved from the modification of compression ratio and ignition timing. The improvement can be compared by higher gradients in Figure 14 as compared to Figure 13. The optimized values shows improvement for the engine.

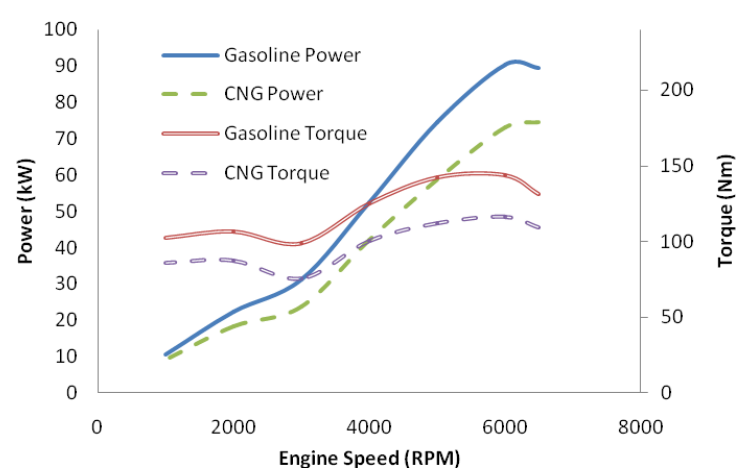

Figure 13: Power and torque curve of gasoline and $\mathrm{CNG}$ without modification.

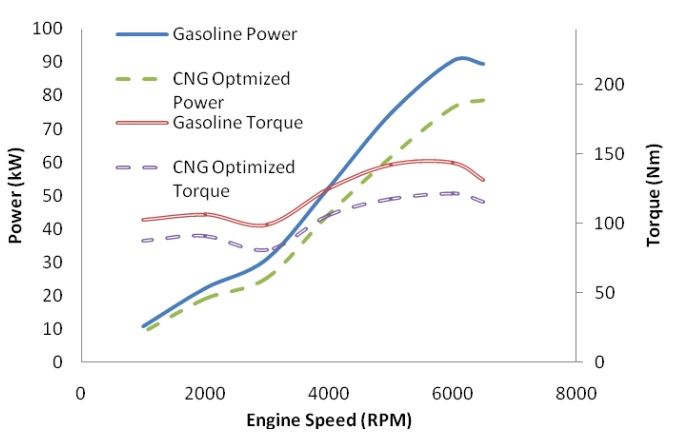

Figure14: Power and torque curve of gasoline and $\mathrm{CNG}$ with optimization

\section{CONCLUSION}

Performance drop is about $15 \%$ from its gasoline counterpart. The $4 \%$ benchmark indicates that the modification to ignition timing and compression ratio does improve engine performance using natural gas as fuel. However, the modification of the engine using compression ratio and ignition timing can be further studied. The only way to increase the power of engine to its original gasoline specification is to apply forced induction system to the engine. A recommendation is that a turbocharged system with slightly lower compression ratio and optimized ignition timing will give the best efficiency.

\section{ACKNOWLEDGEMENTS}

The authors would like to express their deep gratitude to Universiti Malaysia Pahang (UMP) for provided the laboratory facilities and financial support under MOHE FRGS project no. RDU140125 and Automotive Excellence Centre (AEC). 


\section{References}

1. Shafiee, S. and E. Topal, When will fossil fuel reserves be diminished? Energy Policy, 2009. 37(1): p. 181-189.

2. Noor, M.M., A.P. Wandel, and T. Yusaf, Mild combustion: the future for lean and clean combustion. International Review of Mechanical Engineering, 2013. 8(1): p. 251-257.

3. Al-lwayzy, S. and T. Yusaf, Chlorella protothecoides Microalgae as an Alternative Fuel for Tractor Diesel Engines. Energies, 2013. 6(2): p. 766-783.

4. Ghosh, T.K. and M.A. Prelas, NATURAL GAS. Vol. 1. 2009, Columbia: Springer Science + Business Media B.V. 281-381.

5. Supeni, E., et al., Experimental and modeling investigation of the performance characteristics on diesel HCCI with hydrogen additive-a review. National Conference in Mechanical Engineering Research, 2010. 2(1): p. 580-596.

6. Lapidus A.I, K.I.F.T.B.P., Natural Gas as Motor Fuel. Chemistry and Technology of Fuels and Oils, 2005. 41(3): p. 165-174.

7. Hosseini, S.E. and M.A. Wahid, Biogas utilization: Experimental investigation on biogas flameless combustion in lab-scale furnace. Energy Conversion and Management, 2013. 74: p. 426-432.

8. Yusaf, T., et al., Effect of Compress Natural Gas Mixing on The Engine Performance and Emissions. International Journal of Automotive and Mechanical Engineering, 2013. 8: p. 14381451.

9. Hairuddin, A.A., T. Yusaf, and A.P. Wandel, $A$ review of hydrogen and natural gas addition in diesel HCCI engines. Renewable and Sustainable Energy Reviews, 2014. 32: p. 739761.

10. Malaysian Gas, A., Malaysia : Natural Gas Industry Annual Review 2012. 2013. p. 25-25.

11. Ahmad, F. Sustainable agriculture system in Malaysia. in Regional Workshop on Integrated Plant Nutrition System (IPNS), Development in Rural Poverty Alleviation, United Nations Conference Complex, Bangkok, Thailand. 2001.

12. Yu, Z. and F.L. Schanbacher, Production of methane biogas as fuel through anaerobic digestion, in Sustainable Biotechnology. 2010, Springer. p. 105-127.

13. S. Maji, R.R.P.B.S., Comparison of Emmisions and Fuel Consumption from CNG and Gasoline. SAE Technical Paper, 2000(2000-01-1432).

14. Heywood, J.B., Internal Combustion Engine. Vol. 21. 1988, New York: McGraw-Hill, Inc. 219-219.

15. Ramasamy, D., et al., Variation Of Airflow Pattern Through Dissimilar Valve Lift In A Spark Ignition Engine. Journal of the Chinese Institute of Engineers, 2013. 36(8): p. 10831096.
16. Debnath, B.K., N. Sahoo, and U.K. Saha, Thermodynamic analysis of a variable compression ratio diesel engine running with palm oil methyl ester. Energy Conversion and Management, 2013. 65: p. 147-154.

17. Korakianitis, T., A. Namasivayam, and R. Crookes, Natural-gas fueled spark-ignition (SI) and compression-ignition (CI) engine performance and emissions. Progress in Energy and Combustion Science, 2011. 37(1): p. 89112.

18. Yusaf, T., G. Najafi, and D.R. Buttsworth, Theoretical and experimental investigation of SI engine performance and exhaust emissions using ethanol-gasoline blended fuels, in 3rd International Conference on Energy and Environment (ICEE2009). 2009, IEEE Power and Energy Society: Malacca, Malaysia.

19. Ramasamy, D., et al. Mass fraction burn comparison of compressed natural gas and gasoline. in Applied Mechanics and Materials. 2014.

20. White, C., R. Steeper, and A. Lutz, The hydrogen-fueled internal combustion engine: a technical review. International Journal of Hydrogen Energy, 2006. 31(10): p. 1292-1305.

21. Caris, D. and E. Nelson, $A$ new look at high compression engines. 1959, SAE Technical Paper.

22. Anderson, S.T., The demand for ethanol as a gasoline substitute. Journal of Environmental Economics and Management, 2012. 63(2): p. 151-168.

23. Vijayakumar, S., et al., Microwave assisted synthesis of Co 3 O 4 nanoparticles for highperformance supercapacitors. Electrochimica Acta, 2013. 106: p. 500-505. 